\title{
Energy performance and Indoor Air Quality in Modern Buildings in Greenland Case study Apisseq
}

\section{Kotol, Martin; Rode, Carsten}

Published in:

Proceedings of the 7th International HVAC Cold Climate Conference

Publication date:

2012

Link back to DTU Orbit

Citation $(A P A)$ :

Kotol, M., \& Rode, C. (2012). Energy performance and Indoor Air Quality in Modern Buildings in Greenland: Case study Apisseq. In Proceedings of the 7th International HVAC Cold Climate Conference

\section{General rights}

Copyright and moral rights for the publications made accessible in the public portal are retained by the authors and/or other copyright owners and it is a condition of accessing publications that users recognise and abide by the legal requirements associated with these rights.

- Users may download and print one copy of any publication from the public portal for the purpose of private study or research.

- You may not further distribute the material or use it for any profit-making activity or commercial gain

- You may freely distribute the URL identifying the publication in the public portal

If you believe that this document breaches copyright please contact us providing details, and we will remove access to the work immediately and investigate your claim. 


\title{
Energy performance and Indoor Air Quality in Modern Buildings in Greenland - Case study Apisseq
}

Martin Kotol

\author{
Carsten Rode, PhD \\ Member ASHRAE
}

\begin{abstract}
A new dormitory for engineering students "Apisseq" was built in the town of Sisimiut, Greenland in 2010. Its purpose is not only to provide accommodation for students. Thanks to its complex monitoring system it enables researchers to evaluate the building's energy performance and indoor air quality $(\mathrm{LAQ})$ as well as performance of some single components. Some of the installed technologies (balanced mechanical ventilation with heat recovery or solar collectors) are not commonly used in the current Greenlandic building stock. Therefore evaluation of their performance under local conditions is essential for further use and development. The first year of operation has disclosed some errors made during the design process and construction phase which have negative effects on the energy performance and IAQ. The heat demand in 2011 was 26.5\% higher than expected. One of the main causes of the extra heat consumption is the fact that the ventilation system was over-dimensioned, and although it is running on the lowest fan power it maintains $1.1 \mathrm{ACH}$ in the building. Reduction of the air flows and better frost protection of the heat exchangers are important issues to be dealt with in order to decrease the heat demand. This paper describes the building and how it is evaluated after the first year of operation, and it explains some of the revealed problems.
\end{abstract}

\section{INTRODUCTION}

The Greenlandic outdoor climate is cold and dry, so living inside heated buildings results in considerable energy consumption. New energy efficient technologies for better energy performance and healthy indoor environment are not commonly used even in new Greenlandic buildings. With increasing energy prices and demands on healthy indoor environment it can be expected that there will be an increasing need for use of modern energy efficient technologies which will be able to operate in harsh arctic conditions. However designers and contractors have no or limited experience with these technologies and that causes some hindrance to the adoption and proper use of these technologies.

In summer 2010 the new dormitory Apisseq was finished in Sisimiut, Greenland. The intention was to build an energy efficient building in which the modern technologies, not yet commonly used in the Arctic, could be installed and tested. The aim of the technologies has been to minimize the energy consumption and provide the occupants of the building with healthy and comfortable indoor environment.

The building was equipped with a complex monitoring system (Vladyková et al. 2010) which will document the performance of the whole building as well as of some individual systems over their lifetime.

\section{Building key data}

Space solutions. The building has a circular shape and a partially heated ground floor and two upper floors. The total heated area is $1414 \mathrm{~m}^{2}\left(15,220 \mathrm{ft}^{2}\right)$. Main technical room and janitor's office are in the heated part of the ground floor and small storage compartments (one for each apartment) are in the unheated part together with smaller 
technical rooms with ventilation units. The $1^{\text {st }}$ and $2^{\text {nd }}$ floor consist of identical flats. There is a common room with a kitchen and a laundry room on the first floor (Figure 1 shows the first floor plan). On the second floor, the common room and laundry are replaced with flats. In the centre of the building is a glazed atrium with a staircase. Most of the flats are meant to accommodate one person (33 out of $37 \mathrm{flats}$ ). Each flat has an entrance $\left(3.3 \mathrm{~m}^{2} / 35.5 \mathrm{ft}^{2}\right)$, bathroom $\left(2.8 \mathrm{~m}^{2} / 30.1 \mathrm{ft}^{2}\right)$ and living room with a kitchenette $\left(16.8 \mathrm{~m}^{2} / 180.8 \mathrm{ft}^{2}\right)$. At the gables of the building are four bigger apartments for families and handicapped $\left(50.2 \mathrm{~m}^{2} / 540.3 \mathrm{ft}^{2}\right)$.



Figure 1 st floor plan

Constructions. The foundations and the inner load bearing walls and ceilings are made of solid concrete. The insulated envelope consists of wooden timber construction and thermal insulation. The construction is made with a vapor barrier on the warm side of the insulation. The outer surfaces comprise of wind barrier and wooden or cementbased cladding. Windows are gas-filled double-glazed with an additional third pane of glass on the indoor side of the windows. The large balcony window/door is triple-glazed and the fixed parts have a fourth glass pane. See Table $\mathbf{1}$ for calculated U-values.

Table 1. Estimated U-values of the envelope

\begin{tabular}{|c|c|c|}
\hline Construction & $\begin{array}{c}\text { Insulation thickness } \\
\text { [mm]/[in] }\end{array}$ & $\begin{array}{c}\text { R-value } \\
{\left[\left(\mathbf{m}^{2} \cdot \mathbf{K}\right) / \mathbf{W}\right] /\left[\left(\mathbf{h} \cdot \mathbf{f t}^{2} \cdot{ }^{\circ} \mathrm{F}\right) / \mathbf{B t u}\right]}\end{array}$ \\
\hline Floor & $50+200 / 2+8$ & $7.69 / 43.67$ \\
\hline Wall & $290 / 11.4$ & $6.67 / 37.87$ \\
\hline Roof/ceiling & $150+150 / 6+6$ & $7.69 / 43.67$ \\
\hline Windows/door & - & $0.91 / 5.16$ \\
\hline
\end{tabular}

Systems. The building is primarily heated with radiators. In addition the entrances and the bathrooms are equipped with floor heating. Proper ventilation of the building is ensured by two ventilation units. Both are equipped with cross flow heat exchangers and additional after-heating coils connected to the hydronic heating system. Fresh air is being delivered at a constant rate into the living rooms and the exhaust takes place through the kitchen hoods and exhaust air terminal devices (ATDs) in the bathrooms. The exhaust air flow is variable and controlled by the static pressure in the main duct. Kitchen hoods have two damper positions (normal \& cooking) and the ATDs in bathrooms have humidistats. The main source of heat for domestic hot water, space heating and ventilation after heating is district heating. In addition, the building is equipped with 38 evacuated tubular solar collectors placed on the roof. The heat produced by the solar plant is stored in two accumulation tanks $\left(2 \mathrm{~m}^{3} / 528.3\right.$ gal each) and can be used for heating of DHW, space heating and ventilation after-heating. 
Estimated heat demand. The annual heat demand was estimated to $160 \mathrm{MWh} / \mathrm{yr}(543.6 \mathrm{BtuE} 6 / \mathrm{yr})$ for space heating and $80 \mathrm{MWh} / \mathrm{yr}(271.8 \mathrm{BtuE} 6 / \mathrm{yr})$ for DHW. In total $240 \mathrm{MWh} / \mathrm{yr}(815.3 \mathrm{BtuE} 6 / \mathrm{yr})$ or $169.7 \mathrm{kWh} /\left(\mathrm{m}^{2} \cdot \mathrm{yr}\right)$ $\left(53,567 \mathrm{Btu} /\left(\mathrm{ft}^{2} \cdot \mathrm{yr}\right)\right)$. During the first year of operation several investigations and tests were performed in order to evaluate the energy performance of the building and identify possible problems. As the most critical problems were found freezing of the heat exchangers in ventilation units, over-dimensioned ventilation units and poor air-tightness. These problems are negatively affecting energy consumption. As a result, the heat consumption of the building was $214.7 \mathrm{kWh} /\left(\mathrm{m}^{2} \cdot \mathrm{yr}\right)\left(67,772 \mathrm{Btu} /\left(\mathrm{ft}^{2} \cdot \mathrm{yr}\right)\right)$, which is $26.5 \%$ more than expected. The indoor air quality was found to be good except for a period when the ventilation system switched off due to a malfunction. In order to decrease the heat consumption while still keeping the IAQ good, adjustments of some systems are recommended in this paper.

\section{METHODS}

\section{Air tightness}

The air tightness was measured by means of blower door test (Dansk Standard 2001) in two of the single person flats. In order to determine the air tightness, depressurization and pressurization tests were performed on both flats. The reported value is an average from both measurements. The results were then compared to a maximum specific leakage rate of $1.5 \mathrm{l} /\left(\mathrm{s} \cdot \mathrm{m}^{2}\right)\left(2.22 \mathrm{gal} /\left(\mathrm{min} \cdot \mathrm{ft}^{2}\right)\right)$ at $50 \mathrm{~Pa}$ required by the Danish Building Code (Danmark. Erhvervs- og Byggestyrelsen 2010).

Moreover, during the depressurization tests, thermographic pictures were taken from the inside to disclose leakages in the construction.

To determine the air exchange between the adjacent units, we made a tracer gas measurements in six adjacent flats as shown in Figure 2. The tracer gas (Freon) was dosed into flat number 2.07 to obtained constant concentration of $4 \mathrm{ppm}$ and the concentration in all adjacent flats was measured by a gas analyzer Innova. During this test the ventilation system was turned off and the ATDs in all measured flats were sealed with tape. To ensure proper mixing of the air inside the flats, we placed electrical fans into the rooms. The duration of the tracer gas test was 200 minutes.



Figure 2 Tracer gas scheme

\section{Indoor environment}

Five of the flats (this represents $13.2 \%$ of the total number of flats in the building) are equipped with IAQ sensors as a part of the building's monitoring system. Air temperature, $\mathrm{RH}$ and $\mathrm{CO}_{2}$ concentration are measured in the living rooms, and in addition temperature and $\mathrm{RH}$ are measured in the bath rooms. The measurements are taken continuously, but for the sake of this study three successive days in November 2011 were randomly selected. In addition, measurements from three days when the ventilation system was broken down gave us the possibility to investigate the thermal environment and IAQ also for periods when the ventilation system doesn't work.

During the test, only 4 of the monitored flats (10.5\% of total number of flats) were occupied. The evaluation of the indoor environment was done separately for thermal conditions (air temperature) and IAQ $\left(\mathrm{CO}_{2}\right)$ and is shown as the percentage of time the measured variables are within the different categories (Dansk Standard 2007). The four 
categories are: $\mathrm{I}=350 \mathrm{ppm}$, cat.II $=500 \mathrm{ppm}$ and cat.III $=800 \mathrm{ppm}$ above ambient and cat.IV $=$ more than $800 \mathrm{ppm}$ above ambient. As the ambient $\mathrm{CO}_{2}$ concentration $400 \mathrm{ppm}$ was assumed. The airflow was measured by means of air flow hood in the flats and compared with the total air flow given by the ventilation units. The total heat consumption was also of concern since it is expected that the ventilation system plays a significant role in the overall heat demand.

\section{Ventilation units}

For each ventilation unit we measured heat consumption of the after-heating coil, air flows, fan speeds, temperatures and RH on all four connections to the unit. Moreover during the test period, the ventilation units were inspected for frost formation and other possible problems.

The heat consumptions of the after heaters were used to calculate the temperature efficiencies of the heat exchangers.

\section{Heat demand}

During the first months the monitoring system was not completely finished yet, therefore manual readings of the energy meter from district heating company were taken in order to obtain the monthly heat consumptions.

\section{RESULTS}

\section{Air-tightness}

The blower door tests have shown (Table 2), that the specific air leakage is $42 \%$ and $76 \%$ higher than the value $1.5 \mathrm{l} /\left(\mathrm{s} \cdot \mathrm{m}^{2}\right)$ recommended by the Danish building regulation (Danmark. Erhvervs- og Byggestyrelsen 2010).

Table 2. Results of two blower door tests performed on two one person flats

\begin{tabular}{rcc}
\hline & Flat 2.17 & Flat 2.07 \\
\hline \hline Air flow @50 Pa, $\mathrm{V}_{50}[1 / \mathrm{s}] /[\mathrm{gal} / \mathrm{min}]$ & $49.03 / 779.58$ & $61.05 / 970.7$ \\
\hline Air changes @50 Pa, $\mathrm{n}_{50}[1 / \mathrm{h}]$ & 2.94 & 3.66 \\
\hline Permeability @50 Pa, q50 $\left[1 /\left(\mathrm{s} \cdot \mathrm{m}^{2}\right)\right] /\left[\mathrm{gal} /\left(\mathrm{min} \cdot \mathrm{ft}^{2}\right)\right]$ & $0.48 / 0.71$ & $0.62 / 0.92$ \\
\hline Specific leakage @50 Pa, w50 $\left[1 /\left(\mathrm{s} \cdot \mathrm{m}^{2}\right)\right] /\left[\mathrm{gal} /\left(\mathrm{min} \cdot \mathrm{ft}^{2}\right)\right]$ & $2.13 / 3.15$ & $2.65 / 3.91$ \\
\hline
\end{tabular}

Results of tracer gas test showed that dosing of tracer gas into one flat (2.07) doesn't significantly affect the tracer gas concentrations in adjacent flats. From that it could be concluded that there is no significant air exchange between the adjacent flats and thus the major part of the natural air exchange takes place with the outdoors.

The thermographic screening disclosed insufficient sealing between the third removable glass pane and the window frame (Figure 3) in the bathroom. This leakiness causes transfer of the moisture from the indoor space to the window gap with condensation and subsequent freezing on the middle glass pane.

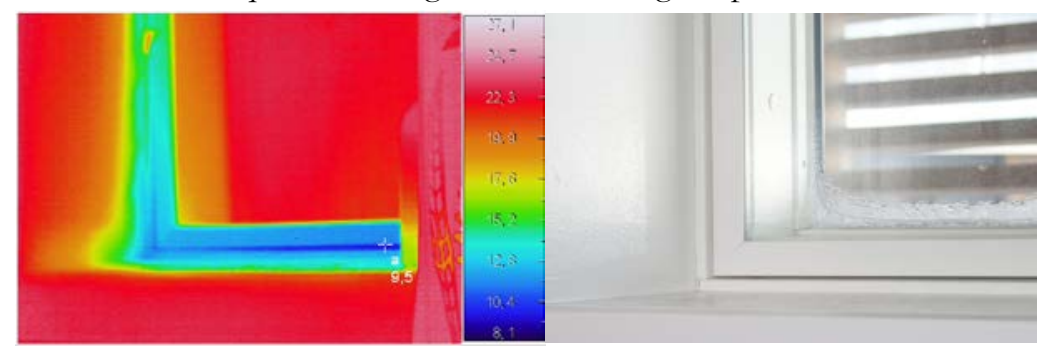

Figure 3 Poor sealing of the third window pane 
Another negative effect on air tightness of the building was due to penetration of the vapor barrier which is placed right behind the interior OSB board by the electrical cable in bathroom.

\section{Indoor environment}

As it is shown in Figure 4, the IAQ was significantly poorer during the period when the ventilation was turned off. On average for $64 \%$ of the examined period, the $\mathrm{CO}_{2}$ concentration was higher than 1200 ppm, which corresponds to indoor environmental category IV (Dansk Standard 2007). On the contrary, during the periods when the ventilation system was in operation, the $\mathrm{CO}_{2}$ levels were as low as to fulfill the best category I of indoor environment for over $88 \%$ of the time in average. The air flows measured in a single person flat at normal conditions (kitchen hood damper in position 1-normal and bathroom ATD at the lowest flow rate) were $70 \mathrm{~m}^{3} / \mathrm{h}\left(2,472 \mathrm{ft}^{3} / \mathrm{h}\right.$ ) on supply ATD, $35 \mathrm{~m}^{3} / \mathrm{h}\left(1,236 \mathrm{ft}^{3} / \mathrm{h}\right)$ on kitchen hood and $35 \mathrm{~m}^{3} / \mathrm{h}\left(1,236 \mathrm{ft}^{3} / \mathrm{h}\right)$ on bathroom ATD. That corresponds to $19.4 \mathrm{l} /$ (s·person) (5.13 gal/(s·person)) or $1.2 \mathrm{ACH}$.

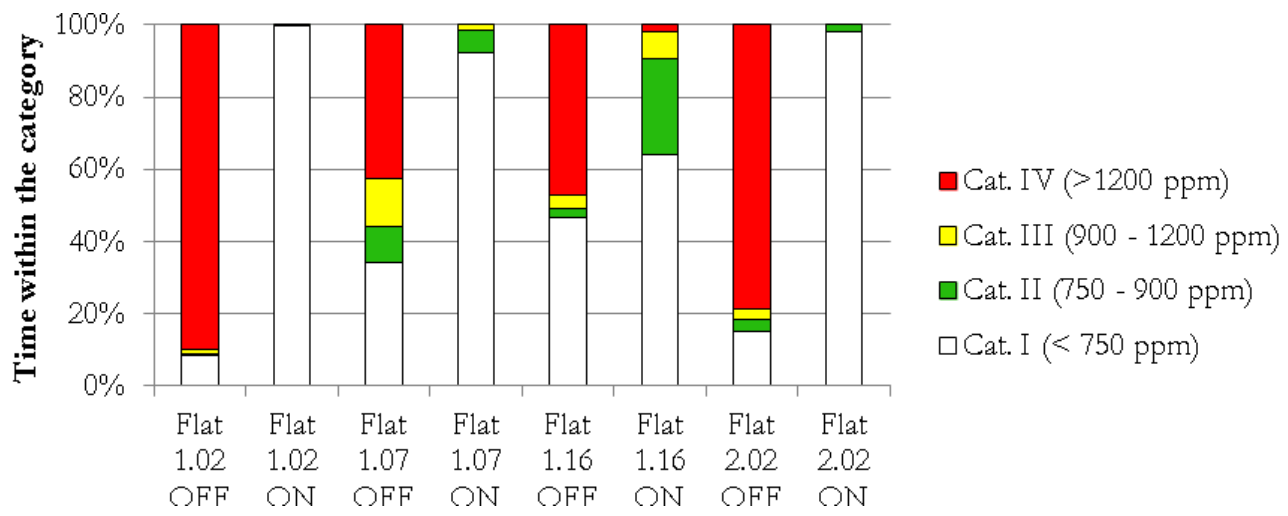

Figure 4 Indoor air quality in \% of time in four indoor environmental categories based on $\mathrm{CO}_{2}$ concentrations above ambient (EN 15251). Ventilation system $O N$ and $O F F$.

During the period when the ventilation system was in operation the air temperature was significantly higher in flats 1.02 and 1.16, but at the same time it was significantly lower in flats 1.07 and 2.02 (Figure 5). The effect of the ventilation system on the thermal environment cannot be judged based on the current study. The average temperature during the whole test period was $24.5^{\circ} \mathrm{C}\left(76.1^{\circ} \mathrm{F}\right)$ and was over $24^{\circ} \mathrm{C}\left(75.2^{\circ} \mathrm{F}\right)$ for $69 \%$ of the time.

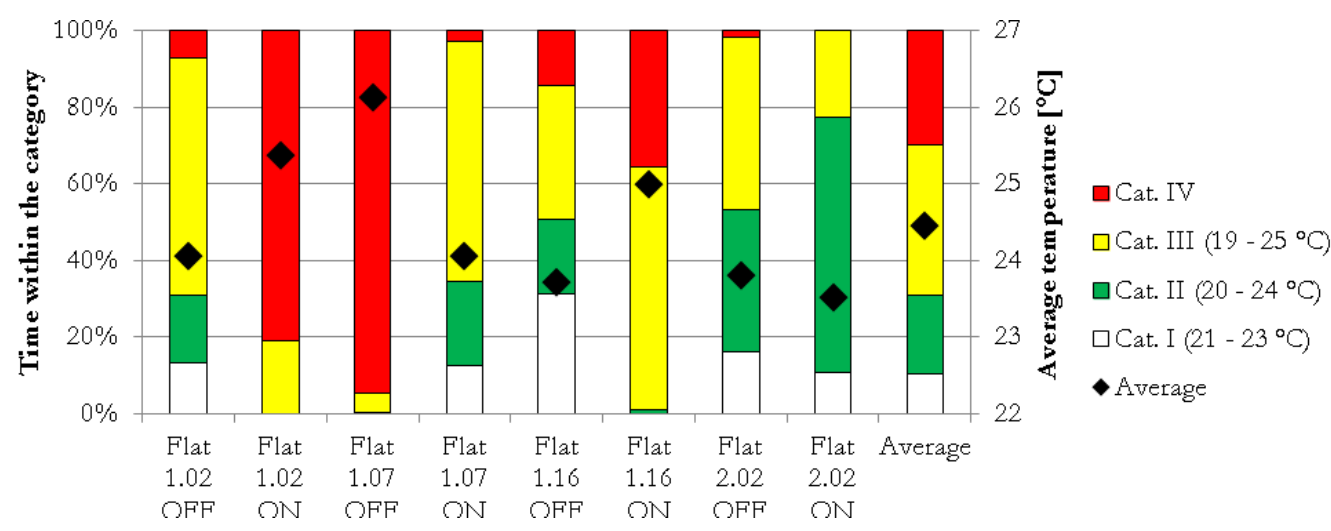

Figure 5 Average air temperatures and thermal environment in \% of time in four indoor environmental categories (EN 15251). Ventilation system $O N$ and OFF. 
The relative humidity was for most of the time within the range from $25 \%$ to $60 \%$ which is the recommended range for category II indoor environment (Figure 6). Significantly lower humidity as a result of dry supply air (20\% in average during the tested period) was maintained when the ventilation system was on.

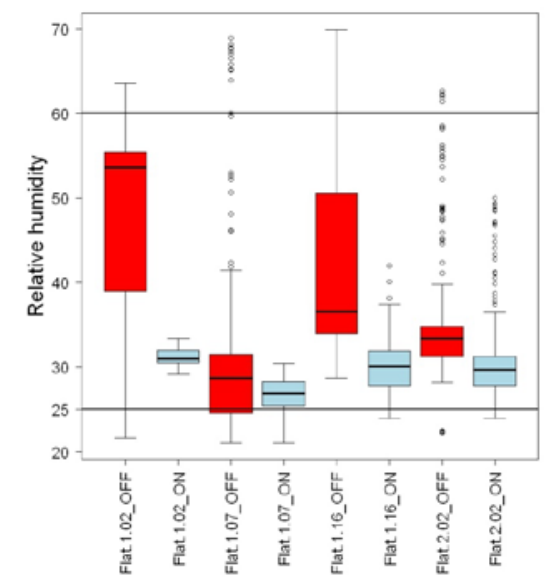

Figure 6 Relative bumidity [\%] in the four flats during the two periods (ventilation OFF and ON)

The heating demand for the period with ventilation in operation (with heating by radiators and heating coil) was $35.5 \%$ higher compare to the period with ventilation turned off (only radiators) (Table 3).

Table 3. Energy consumption during the two examined periods

\begin{tabular}{cccc}
\hline $\begin{array}{c}\text { Ventilation } \\
\text { [ON/OFF] }\end{array}$ & $\begin{array}{c}\text { Heating Degree Days } \\
\left.\text { [HDD }\left({ }^{\circ} \mathbf{C}\right)\right] /\end{array}$ & $\begin{array}{c}\text { Total Heating Energy } \\
\text { [kWh]/[BtuE6] }\end{array}$ & $\begin{array}{c}\text { Heat demand } \\
\text { [kWh/HDD] } / \\
\text { [BtuE6/HDD] }\end{array}$ \\
\hline \hline $\mathrm{ON}$ & $78.5 / 141.3)]$ & $2,245 / 7.6$ & $28.6 / 0.054$ \\
$\mathrm{OFF}$ & $80.7 / 145.26$ & $1,706 / 5.8$ & $21.1 / 0.040$ \\
\hline
\end{tabular}

\section{Ventilation units}

Significant frost formation was found on both heat exchangers as a result of a malfunctioning defrosting strategy. This feature (as we found later) was not ordered by the investor and the units are not equipped with it.

We also discovered that during periods with snowfall, the snow is transported with the supply air and accumulates inside the ventilation unit. The water collecting tray is only placed under the exhaust part of the heat exchanger to collect condensate, but when snow in the supply part melts, the water has no drainage and can cause serious problems such as mould growth and subsequent spread of pollutants into the living spaces.

The ventilation units are running under normal conditions (no increased exhaust air flow) on the lowest possible fan speed, i.e. only on $14 \%$ of the maximum. The air flows are slightly imbalanced even at normal conditions which can be explained by the wrong regulation of the unit. The exhaust air flow during the tested period was in average $10 \%$ higher than supply. The air flow rate measured during the tested period at the unit level corresponds to an overall air exchange rate of $1.1 \mathrm{~h}^{-1}$, which corresponds to the results obtained from measurements in the flats.

The average temperature efficiency of the heat exchangers over the tested period with ventilation units turned on was $52.6 \%$. It is likely that the low efficiency is caused by the frost formation inside the heat exchanger which reduces the heat transfer.

\section{Heat demand}

The amount of heat delivered by district heating in 2011 was 303.6 MWh (1031.4 BtuE6) or 214.7 kWh/(m².yr) 
$\left(67,772 \mathrm{Btu} /\left(\mathrm{ft}^{2} \cdot \mathrm{yr}\right)\right)$. With the current price of heat the annual heating bill was $33,400 €$. Monthly heat consumption, number of heating degree days (HDD) and heat demand per HDD ratio can be seen in Figure 7. It is obvious from Figure 7 that the winter heat demand varies from 40 to $45 \mathrm{kWh} / \mathrm{HDD}$ and is significantly lower during summer when there is more solar energy available. The disturbance in May is caused by a malfunction of the solar heating system where it was out of order for a longer period.

We also found that the current setup of the solar heating system does not allow the heat from accumulation tanks to be transferred to the heating system and is therefore only used for DHW heating.



Figure 7 Annual heat consumption in 2011 and heat demand per HDD

\section{DISCUSSION}

\section{Air-tightness}

The air-tightness off the building would not fulfill the Danish requirements, but there are no requirements on air-tightness in the Greenlandic building code. It is assumed that great improvement could have been achieved if a gap for building services had been installed between the vapor barrier and the inner surface. In such a way the number of penetrations of the vapor barrier would have been limited. With blower door testing of the building during the right stages of construction, some leakages could have been detected and it would have been possible to fix them.

It was discovered that the third window pane in the bathroom was insufficiently sealed. This causes condensation problems that could lead to mould growth. Proper sealing of the third glass pane in a frame which is not robust enough will be technically difficult. The use of highly efficient triple glazed windows instead of double glazed with extra pane could eliminate this problem.

\section{Indoor air quality}

The indoor air quality in periods with ventilation system turned ON fulfils the indoor environmental category I according to (Dansk Standard 2007). When compared to the case with the ventilation system turned off, the heat demand is $33 \%$ higher, but the IAQ is significantly better. In order to decrease the energy consumption, it is suggested to reduce the air exchange so that the indoor environment category II recommended for new buildings will be fulfilled. Unfortunately this will not be possible with the existing ventilation units since they are too oversized.

\section{Ventilation units}

To avoid freezing of the heat exchangers the units need to be equipped with proper frost protection. The bypass damper should be controlled by a combination of outdoor temperature, dew point of the extracted air and pressure loss of the heat exchanger. This way the accumulation of ice will be detected in advance, and there will be enough time to activate the damper and protect the heat exchanger from getting blocked by the ice accumulation. To avoid the 
intake of snow into the ventilation unit, protecting shields should be installed. The change of the ventilation units should be considered. It will bring large energy savings if the air flows are reduced. Both heat and electricity demand will decrease, and the efficiency of the heat exchangers will be higher thanks to the frost free operation.

\section{Heat demand}

The overall heat consumption over the first year of operation was lower than the average in Greenlandic dwellings which according to (Statistics Greenland 2011) is $373 \mathrm{kWh} /\left(\mathrm{m}^{2} \cdot \mathrm{yr}\right)\left(117,813 \mathrm{Btu} /\left(\mathrm{ft}^{2} \cdot \mathrm{yr}\right)\right)$. It was however $26.5 \%$ higher than expected. The reasons for the higher consumption are several:

- Too high air exchange.

- Low heat recovery efficiency decreased by the frost formation.

- The contribution of the solar heating to the yearly heat performance was limited by the malfunctions and also by wrong setup.

- Occupant behaviour (too high space temperature, DHW consumption, windows opening).

- Poor air tightness.

It is assumed that some of the problems can be eliminated and the heat demand can be decreased more towards the design value.

\section{CONCLUSIONS}

The building provides the occupants with good indoor air quality. The humidity level in the living spaces is kept low which eliminates the risk of mould growth; on the other hand it can be too low during colder periods and might cause irritation to the occupants of their mucous membranes and dry skin. Too high air exchange, high indoor temperature, lower air tightness, lower heat recovery efficiency of the ventilation units, occupant behavior and some malfunctions on technical systems during the first year of operation are the main reasons for higher heat demand than expected.

In future projects with ambitions for high energy efficiency and good IAQ great attention must be paid to the design phase of the projects. Proper sizing of the systems is essential for the good result. Also commissioning process, both for design and construction of the building could avoid some problems.

Investigation of the dormitory will continue for the upcoming years consisting of more detailed long-term measurements, simulations and questionnaire studies in order to provide new knowledge of modern systems in cold Arctic.

\section{REFERENCES}

Bjarlov, S.P. \& Vladykova, P. 2011, "The potential and need for energy saving in standard family detached and semidetached wooden houses in arctic Greenland", Building and Environment, vol. 46, no. 8, pp. 1525-1536.

Danmark. Erhvervs- og Byggestyrelsen 2010, Bygningsreglement 2010 (BR10), Erhvervs- og Byggestyrelsen, Kbh.

Dansk Standard 2007, DS/EN 15251 - Indoor environmental input parameters for design and assessment of energy performance of buildings addressing indoor air quality, thermal environment, lighting and accoustics, Dansk Standard, Charlottenlund.

Dansk Standard 2001, Bygningers termiske ydeevne - bestemmelse af luftgennemtrængelighed i bygninger prøvningsmetode med overtryk skabt af ventilator $=$ thermal perfomance of buildings - determination of air permeability of buildings - fan pressurization method, Dansk Standard, København.

Statistics Greenland 2011, 14.11.2011-last update, Grønlands energiforbrug. Available: http: $/ /$ www.stat.gl $/$ dialog $/$ main.asp?lang $=$ da\&version $=200901 \& l i n k=E N \& s u b t h e m e c o d e=p 2 \&$ colcode $=p$ [2011, 10.6.2011].

Vladyková, P., Kotol, M., Vladyková, P. \& Kotol, M. 2010, Monitoring system in new dormitory APISSEQ, Sisimiut, Greenland, DTU Byg. 